\title{
"Peace, Like War, Must Be Waged"
}

$\mathrm{D}^{\mathrm{n}}$

R. Vannevar Bush's brave words, used as the title of this greeting to members of the Association of College and Reference Libraries, set the pace at which I hope we may work together during 1945-46. Our country and its allies have won our war; the long battle for enduring peace seems hardly to have been joined. Public opinion, if rightly informed and energized, may just barely save the day. And so the call is clear to librarians who collect, keep, organize, dispense, expend, expound the wisdom of the ages to go forward in their work for peace with the same standards of achievement that have been the glory of the armed forces in time of war. Within this frame of reference, may I suggest three lines of endeavor for our consideration?

First, the creation of a stronger, more productive association. The reorganization of the College and Reference Section, 1936-38, which resulted in the present association, brought together over eight hundred members; in December 1944 the membership numbered 2223. This is a fine rate of growth. If it can be accelerated now, without a time-lag, there is every hope that a membership of five thousand eventually will increase our manpower and our funds, will adequately support our committees in their work, and will bring into being new lines of accomplishment to meet the needs of the times. To this end, each individual member, each head of a reference department, each head librarian, all specialists in educational librarianship, are besought to constitute themselves recruiting officers for the maximum membership in the association.

The learned societies of the United States are bulwarks of its intellectual life, as witness the contributions of groups of scientists to the winning of the war. A.C.R.L. should not "cease from mental fight" until it has an organization as good in its own sphere as the best organizations in other fields.

As one means of the accomplishment of this greatly desired end, on June 23, I945, the officers and directors, under the leadership of Winifred Ver Nooy as president, made an application to the Executive Board of the A.L.A. for a service which has been requested repeatedly over a period longer than ten years. The application calls for a specialist on the staff of A.L.A. Headquarters who will serve the particular needs of all groups whose collective strength forms the A.C.R.L. Research and information, consultation and advice, promotion and development of reference, research, and educational librarianship, are envisaged as the contributions to be stimulated by such an appointment.

In spite of the sympathy and courtesy with which the case was heard and the making of certain suggestions of possible future developments, the board has not yet notified the A.C.R.L. of affirmative action on its request. The situation is a difficult one, since the A.L.A. has heavy commitments to projects already launched, as well as an imposing list of applications for support of new undertakings. It cannot be denied, however, that there seems to exist some 
lack of understanding of the value that would accrue to the achievements and reputation of the whole A.L.A. from the work of a specialist devoted to the scholarly interests that exist in all libraries, functionally, without being confined to any one type of institution. The A.C.R.L. must certainly bear its own share of the blame for failing in the past to press its claims to a point where a final decision was reached and for lacking a unified will to win objectives in which it believes devotedly. Under these circumstances, it is of first importance for the association to decide how it will pursue these aims in the future and in what direction its best development lies. The president for $1945-46$ solicits guidance and direction from the membership to advance such understanding throughout the year.

Second, the development of devices for wide distribution of the formative ideas, the discoveries, the innovations that are even at this moment making history in many a library off as well as on the beaten path. I should like to see many more librarians publishing the results of their work, not in essays consisting of general statements based on questionnaires, but as laboratory reports of work in progress. Such reports are familiar mechanisms in other fields of scholarship. To no profession can they possibly be more useful than to one still in the active stage of assembling its source materials.

Our own journal, College and Research Libraries, now essential reading for a growing number of us, has succeeded in publishing original material of unusual value. Even judged by so gross a measure as its financial situation, it is a success. Rarely, indeed, have so many owed so much to so few, as its readers have owed to its editors. With a considerably enlarged subscription list, which seems to be in the making, it is not utopian to hope for this journal a growth in size that will accommodate much more laboratory material. Provision of such data when new and useful should then be assumed as a professional obligation by all members of the A.C.R.L.

In addition to formal and informal publications on an increased scale, we need a subject index in a central place (preferably in the office of a specialist at A.L.A. Headquarters) of the undertakings of all libraries in the college and reference field. From such an index a consultant service of real power could be developed for large as well as small libraries. Questions to be answered would have a wide range, as for example, Is there a satisfactory testing device for finding out a freshman's ability to use a college library? What is being done to make displays and exhibits useful in teaching subject material? What applications are being made by teacher-training colleges of such documents as the Yale and Harvard reports on long-term educational planning? How does an institution conduct an architectural competition for a new building so that it is ine with the practices approved by the American Institute of Architects? What are the promising new ideas for library buildings? What should reference libraries be preparing to do in view of pending legislation in support of research on a national scale? Could libraries assume responsibility for carrying on the courses in reading and communication recently given by the Army? Some of this material is hidden away in graduate theses; infinitely much more is discovered and practiced in isolated instances, with no carry-over that is fruitful for librarianship as a whole. To do good and to be willing to communicate is sound scripture and an equally important enterprise to which A.C.R.L. may well dedicate itself.

Third, the stimulation of librarianship as a learned profession, to meet the challenge of the atomic age, whatever that challenge may be. In the past librarians have been timid about calling themselves 
educators, so that it came with something of a shock when the New York Times, on Aug. 4, 1945, published an editorial in support of "another large group of teachers ... the city's librarians." But to anyone whose duty it is to read the bills now before Congress on the promotion of scientific research for the public good, it seems quite possible that as a nation we are moving into a greatly improved understanding of the value of knowledge and research, with their attendant spirits: books, libraries, and librarians. Professor Einstein's comment that even if atomic bombs destroy two-thirds of the human race there will be enough men and enough books left to start over again sheds the light of a great mind on the place of books in the world of tomorrow. How, then, are these books to be served and serviced so that the teaching function of libraries will be developed on a scale to meet opportunities as they come?

Certainly this will not be accomplished by continuing to think in the categories that meant progress thirty years ago. American librarianship has gone through its technological revolution, and great are the blessings that have resulted. Now it seems evident that a new division of labor should be made, as long ago it was made in another great institution of our civilization, the hospital. Obviously, libraries will always need laboratory technicians and attendants, just as hospitals need laboratory technicians and nurses. Quantitatively this will continue to be the larger demand. At some levels it may be the only demand, with the result that professional training for such work should be more rather than less practical, highly energized, and socially conscious.

The instant the real teaching function of a library is emphasized, however, the teacher must know a great deal more than the taught. If he cannot be a man of universal learning in One World swollen with books, he can at least be a thinker whose capacity has been tested by the highest standards of formal education or proved by the quality of his independent research. Within the disciplines of our universities there is ample opportunity for selecting subject fields particularly appropriate to librarianship. Comparative literature, comparative government, public administration, the history of science, the history of artto mention only a few-could provide congenial specialization for the advanced student who would go also to the school of librarianship for his bibliographical work and for the special slanting of his interest that any profession requires. The members of A.C.R.L. could hardly perform a more statesmanly service to their profession than to initiate investigations that would result in new definitions of librarianship on varying levels of opportunity, responsibility, and reward. As early as $1902 \mathrm{Dr}$. William Warner Bishop wrote an illuminating paper, "Should the Librarian Be a Bibliophile?" Forty-three years later librarians such as he called for are still rare. Have we not waited long enough to be active in helping to produce them?

About these and many other ideas and plans your new president needs your advice, instruction, admonition, and most of all your help. Will you not write to me, giving me my marching orders? 